\title{
The Correlation of Pain Catastrophizing Scale and Sedation in Patients Undergoing Gastroscopy
}

\section{Gastroskopi Yapılan Hastalarda Ağrı Katastrofizasyonu ile Sedasyon İlişkisi}

\section{(D) Pınar Duman Aydın¹, (D) Ahmet Akbaş2, (D) Ahmet Şen¹}

${ }^{1}$ University of Health Sciences Turkey, Trabzon Kanuni Training ve Research Hospital, Clinic of Anesthesiology and Reanimation, Trabzon, Turkey 2University of Health Sciences Turkey, Bağcllar Training and Research Hospital, Clinic of Oncology, İstanbul, Turkey

\section{Abstract}

Objective: Catastrafization is defined as considering the worst possible consequence of events and danger and increasing the likelihood of this. In this study, the Catastropization scale applied to patients to compare pain catastrophization before the esophagogastroduedonoscopy procedure and the pain at the vascular access of patients and the amount of sedation applied were compared.

Method: Patients planned for esophagogastroduodenoscopy were informed about the pain catastrophizing scale before the procedure and asked to answer the form. The pain of the patient during vascular access was recorded according to the numerical pain rating scale. Sedation was applied to all patients during the esophagogastroduedonoscopy procedure. Sedation relationship applied to the patient was evaluated by both pain assessment methods.

Results: A positive correlation was observed between the intensity of pain during vascular access (DyNRS) and the amount of sedation applied during endoscopy, and between Pain Catastrophizing scale and DyNRS.

Conclusion: In this study, it was concluded that there was a relationship between the intensity of vascular pain and sedation consumption, and the amount of sedation consumption will increase as the level of pain increases.

Keywords: Endoscopy, numeric rating scale, pain catastraphizing scale, sedation

\section{Öz}

Amaç: Katastrafizasyon, olaylar ve tehlikeyle ilgili olabilecek en kötü sonucu düşünüp bunun olabilirliğini artırmak olarak tanımlanmaktadır. $\mathrm{Bu}$ çalışmada özefagogastroduedonoskopi işlemi öncesi ağrı katastrofizasyonunu belirlemek için hastalara uygulanan katastrafizasyon skalası ile hastalara damar yolu açılışındaki ağrısı ve uygulanan sedasyon miktarı karşılaştıııldı.

Yöntem: Özefagogastroduodenoskopi planlanan hastalar işlem öncesinde acı felaket ölçeği hakkında bilgilendirildi ve formu cevaplamaları istendi. Hastanın damar yolu açma esnasındaki ağrısı Numerik Ağrı Değerlendirme skalasına göre kaydedildi. Tüm hastalara özefagogastroduedonoskopi işlemi esnasında sedasyon uygulandı. Her iki ağrı değerlendirme yöntemi ile hastaya uygulanan sedasyon ilişkisi değerlendirildi.

Bulgular: Hem vasküler erişim sırasında ağrının yoğunluğu (DyNRS) ile endoskopi esnasında uygulanan sedasyon miktarı arasında hem de Acı Felaket ölçeği ile DyNRS arasında pozitif yönde korelasyon görüldü.

Sonuç: Bu çalışmada, damar yolu ağrı şiddeti ile sedasyon tüketimi arasında bir iliş̧ki olduğu ve ağrı düzeyi arttıkça sedasyon tüketim miktarında da artış olacağı sonucuna varıımıştır.

Anahtar kelimeler: Ağrı katastrafizasyon skalası, endoskopi, numerik değerlendirme skalası, sedasyon

Address for Correspondence: Ahmet Akbaş, University of Health Sciences Turkey, Bağcılar Training and Research Hospital, Clinic of Oncology, İstanbul, Turkey

E-mail: draakbas@hotmail.com ORCID: orcid.org/0000-0002-6333-4919 Received: 23.06.2020 Accepted: 31.08.2020

Cite this article as: Duman Aydın P, Akbaş A, Şen A. The Correlation of Pain Catastrophizing Scale and Sedation in Patients Undergoing Gastroscopy. Bagcilar Med Bull 2021;6(1):1-6.

${ }^{\circ}$ Copyright 2021 by the Health Sciences University Turkey, Bagcilar Training and Research Hospital Bagcilar Medical Bulletin published by Galenos Publishing House. 


\section{Introduction}

The presence of alarm symptoms such as dysphagia, vomiting, gastrointestinal bleeding, anemia, anorexia and loss of weight could indicate malignancy in patients over the fifty years of age. The primary method of diagnosis is upper endoscopy $(1,2)$. Endoscopic procedures are used for monitoring, screening and treatment of benign or malignant lesions (3). Today, it is very important to ensure the comfort of the patient during endoscopy. Sedation facilitates the work for both the physician and the patient, particularly due to the prolongation of the procedure in cases where biopsy is performed for diagnostic purposes or during endoscopy performed for treatment. Sedation is preferred by the endoscopist and the patient since it reduces anxiety, causes short-term retrograde amnesia and enables the patient to feel less pain during the procedure. Administration of sedation may vary according to the experience of the anesthetist, nature of the procedure applied to the patient, experience of the endoscopist regarding the procedure, and the sociocultural state of the patient.

Previous studies have shown that the cognitive state of the individual plays an important role in sensing the pain and evaluating the intensity. Catastrophizing has been defined as "thinking about the worst possible consequence regarding the cases and threat and increasing likelihood of experiencing". "The pain catastrophizing scale" (PCS) was developed by Sullivan et al. (4) in order to evaluate the severity of catastrophizing.

In the present study, we aimed to investigate the correlation between the amount of sedation consumed during endoscopic procedures with the intensity of pain during vascular access (DyNRS) and PCS.

\section{Materials and Methods}

This retrospective observational cross-sectional study was carried out in the University of Health Sciences Turkey, Trabzon Kanuni Training and Research Hospital Clinic of Endoscopy after obtaining the approval from the Clinical Research Ethics Committee (13/03/2020-KAEK-2020/15) of the same hospital.

Patients over the 18 years of age, who were admitted to the general surgery, internal medicine and gastroenterology clinics with epigastric complaints and planned for elective esophagogastroduodenoscopy (EGD), were included in the study after obtaining written and verbal informed consent. An evaluation was performed prior to endoscopy, and the emergency patients, patients with coagulopathy and infection, patients who were not administered sedation, patients who received long-term opioid treatment due to psychiatric diseases, and patients who did not desire to participate in the study were excluded.

At the preparation room before the endoscopic procedure, gender, age, body mass index (BMI), educational background, chronic pain information, smoking habits, comorbidities of the patients were recorded along with the drugs they used regularly. Patients were informed about the numeric rating scale (NRS). Next, the patients were informed about the PCS and asked to complete the PCSTR form. Prior to the procedure, the non-dominant hand skin was cleansed with alcohol and venous vascular access was opened with an 18 Gauge needle. The pain experienced by the patient during the opening of the vascular access was recorded according to NRS (vascular access NRS= DyNRS). All perioperative procedures and follow-ups were carried out by a single anesthetist. During EGD, sedation was administered to all patients with intravenous $1 \mathrm{mg} /$ $\mathrm{kg}$ propofol. In cases where patients experienced pain during the procedure or moved in a way to prevent the procedure, $0.3-0.5 \mathrm{mg} / \mathrm{kg}$ intravenous propofol was applied as additional dose and it was recorded.

Pain intensity: The presence and severity of pain experienced during the opening of the venous access was evaluated by NRS of $10 \mathrm{~cm}(0=$ no pain, $10=$ maximum pain $)$. NRS is a reliable method, which evaluates the subjective pain intensity, does not require verbal or literacy skills, is easy to use and is accepted by in the global literature (5).

PCS: PCS was developed in order to determine the pain catastrophizing in 1995. The Turkish version was tested for reliability and validity by Suren et al. (6) and the Cronbach alpha coefficient was found to be 0.90 . It consists 13 questions in 3 different question types, which are rumination, magnification and helplessness. Each question is scored between 0 and 5 . The total score to be obtained from the scale ranges from 0 to 52 . The high scores indicate negative results (4).

\section{Statistical Analysis}

Descriptive analyses were performed in order to provide information regarding the general characteristics of the study groups. Data related to the continuous variables were given in the form of mean \pm standard deviation and categorical variables were given as $\mathrm{n}$ (\%). Comparisons between the groups were made using the Mann-Whitney $\mathrm{U}$ test and associations were expressed as the Spearman's rank correlation coefficients $\left(r_{s}\right)$. The p-values were 
accepted to be statistically significant when they were calculated as below 0.05. A package statistics software was used for calculations (IBM SPSS Statistics 19, SPSS inc., an IBM Co., Somers, NY).

\section{Results}

The number of patients included in the study was 64 (18 male and 46 female), the mean age was $39.8 \pm 11.9$ years and the BMI was $26.7 \pm 5 \mathrm{~kg} / \mathrm{m}^{2}$. When the vascular access was opened during premedication prior to the endoscopy, the median pain intensity value of the patients was measured as (DyNRS) 2 (1-4), the median PCS was 17.50 (10-31.50) (Table 1), the duration of the endoscopy procedure was $5.53 \pm 2.15$ minutes and the amount of propofol used for sedation was observed to be $80.3 \pm 16.2 \mathrm{mg}$ (Table 2 ).

When we analyzed analgesic needs, we showed that patients having normal PCS scores needed significantly lower doses of analgesic premedication than patients having higher PCS scores (median rank scores $21.61 \mathrm{mg}$ vs $40.97 \mathrm{mg}$, $\mathrm{p}<0.001$ ) (Table 3). Similarly, patients having low DyNRS values $(<4)$ needed significantly lower doses of analgesic premedication than patients having higher DyNRS values $(\geq 4)$ (median rank values $30.99 \mathrm{mg}$ vs. $36.60 \mathrm{mg}, \mathrm{p}=0.044$ ) (Table 3).

No significant relationship was observed in statistical evaluations performed for educational background, BMI and smoking habits ( $\mathrm{p}>0.05$ ) (Table 3 ).

A significant positive correlation was observed between DyNRS and endoscopy and the amount of sedation administered during endoscopy $\left(\mathrm{r}_{\mathrm{s}}=0.407, \mathrm{p}=0.040\right)$. A positive correlation was observed between PCS and DyNRS

Table 1. Demographic features of pain scores

\begin{tabular}{lllll} 
& $\begin{array}{l}\text { Lower } \\
\text { quartile (Q1) }\end{array}$ & Median & $\begin{array}{l}\text { Upper quartile } \\
\text { (Q3) }\end{array}$ & Min-max \\
\hline PCS & 10 & 17.50 & 31.50 & $2-51$ \\
DyNRS & 1 & 2 & 4 & $0-8$ \\
\hline
\end{tabular}

PCS: The pain catastrophizing scale, DyNRS: The intensity of pain during vascular access

Table 2. Demographic features of patients

\begin{tabular}{lll} 
& Mean \pm SD & Min-max \\
\hline Age (year) & $39.8 \pm 11.9$ & $20-63$ \\
BMI $\left(\mathbf{k g} / \mathbf{m}^{2}\right)$ & $26.7 \pm 5.1$ & $20.7-34.1$ \\
Total sedation amount $(\mathbf{m g})$ & $80.3 \pm 16.2$ & $55-130$ \\
Endoscopy time (min) & $5.53 \pm 2.15$ & $3.17-8.25$ \\
\hline
\end{tabular}

BMI: Body mass index, SD: Standard deviation $\left(\mathrm{r}_{\mathrm{s}}=0.390, \mathrm{p}=0.033\right)$. Moreover, there was a significant positive correlation between PCS and the amount of propofol used during endoscopy for sedation $\left(\mathrm{r}_{\mathrm{s}}=0.545\right.$, $\mathrm{p}=0.000$ ) (Table 4).

\section{Discussion}

In the present study, it was aimed to determine the PCS level during the preoperative period and to estimate the sufficiency of sedation during the procedure as well as providing the patients with a comfortable experience. In addition, the correlation between PCS and DyNRS was also discussed.

When used in appropriate doses, sedation and analgesia improves the comfort of both the patient and the clinician in day surgeries. It also increases the achievement level of the procedure. Therefore, planning is important for providing an effective and reliable analgesia (7). Hence, the pain that is experienced at all degrees of severity, regardless of localization in the perioperative process of day surgeries, may cause functional disorders in all organs and lead to complications such as the increase in morbidity and mortality.

Table 3. Comparison by total sedation amount of demographic and clinical features of patients

\begin{tabular}{lllll} 
& & $\mathbf{n}$ & Mean ranks & $\mathbf{p}$ \\
\hline \multirow{2}{*}{ PCS } & $<17$ & 28 & 21.61 & \\
\multirow{3}{*}{ Gender } & $\geq 17$ & 36 & 40.97 & $\mathbf{0 . 0 0 0 *}$ \\
& Female & 46 & 31.50 & \\
\multirow{3}{*}{ Smoking } & Male & 18 & 35.06 & $0.485^{*}$ \\
& Yes & 17 & 31.71 & \\
BMI (kg/m $\left.{ }^{2}\right)$ & $\geq 20-<25$ (normal) & 19 & 28.95 & $0.835^{*}$ \\
& $\geq 25$ (overweight) & 39 & 29.77 & $0.860^{*}$ \\
DyNRS & $<4$ & 43 & 30.99 & \\
& $\geq 4$ & 21 & 35.60 & $0.044^{*}$ \\
\hline
\end{tabular}

*: Mann-Whitney U test, PCS: The pain catastrophizing scale, DyNRS: The intensity of pain during vascular access, BMI: Body mass index, The significant p-values were marked as bold characters.

Table 4. Correlation between pain scores and the amount sedation

\begin{tabular}{llll} 
Correlation & $\mathbf{n}$ & Spearman's rho $\left(\mathbf{r}_{\mathbf{s}}\right)$ & $\mathbf{p}$ \\
\hline Sedation amount-PCS & 64 & 0.545 & $\mathbf{0 . 0 0 0}$ \\
Sedation amount-DyNRS & 64 & 0.407 & 0.040 \\
PCS- DyNRS & 64 & 0.390 & 0.033 \\
\hline
\end{tabular}

PCS: The Pain Catastrophizing scale, DyNRS: The intensity of pain during vascular access, $r_{s}$ : Spearman's rank correlation coefficients, The significant $p$-values were marked as bold characters. 
Pain perception is a complex experience that includes emotional and behavioral components in addition to physiologic components. It becomes more difficult to reduce the pain in individuals with previous experience of pain or who believe that they have excessive pain. This relationship between the catastrophizing and severity of pain has not been fully clarified yet (4).

Vascular access is a compulsory intervention in order to administer and continue anesthesia in patients undergoing surgery. Vascular access is a painful and stressful intervention for patients. They usually state that they experience this pain quite intensively. It is reported that the cognitive perception of the individuals regarding pain and their psychological conditions are important when perceiving the intensity of the needle pain $(5,8)$. In the same study, a relationship was found between DyNRS level and pain catastrophizing. Based on this relationship, certain advantages such as early mobilization and reduced complications and hospitalization could be achieved through appropriate analgesia $(9,10)$. In our study, the amount of sedation administered to the patients with high levels of DyNRS during vascular access was found to be high. The level of PCS was also found to be high in patients with high DyNRS levels.

It was demonstrated that the patients with high PCS levels had more analgesic needs (11). In their study on patients undergoing total knee arthroplasty, Wright et al. (12) concluded that patients catastrophizing pain experienced more intensive pain during the postoperative period, and their needs for analgesic increased. In our study, we believed that sedation and the amount administered would be sufficient for determining how patients reflected their previous experiences of pain during vascular access and short-term procedures; therefore, there was no monitoring for the level of analgesia. The amount of sedation was found to be correlatively low in patients with low levels of PCS.

The results of our study regarding the PCS and DyNRS indicated that there could be positive correlation between PCS value and the vascular access pain intensity, similar to the results of the study by Suren et al. (6). Various studies have concluded that PCS value could predict the intensity of postoperative pain and the amount of analgesic consumption $(8,13)$. In addition, the PCS value could predict both vascular access and postoperative pain intensities as well as analgesic consumption; therefore, the intensity of postoperative pain could be predicted by evaluating the vascular access pain (6).
The insufficient level of postoperative analgesia could extend the inpatient period $(14,15)$. In our study, we did not monitor postoperative pain due to the short period of procedure; however, we could predict the pain intensity of the patient by monitoring the sedation level of the patient during the procedure. In addition, our monitoring methods did not include the hospitalization period; however, Tharakan and Faber (16) demonstrated a directly proportional relationship between hospitalization period and the consumption of analgesics. In the light of these data, we can conclude that when a sufficient level of sedation is administered to the patient during the procedure, we believe that the intensity of pain would also be low and the patient could be discharged from the health facility in a short time after the procedure. However, this was not the direct conclusion of our study, it was rather a secondary outcome.

In previous studies, different values have been observed for PCS. In their study, Pavlin et al. (17) found it to be 13, and Lautenbacher et al. (18) calculated it on patients of malignancy surgery as 19.38. In their study on 134 healthy individuals, Ruscheweyh et al. (19) calculated it as 10.7 in terms of headache, 11.0 in terms of backache and 16.7 in terms of toothache in young adults (20-40 years of age). They also determined it to be 13.3 in terms of headache, 13.5 in terms of backache and 13.5 in terms of toothache in the elderly (50-70 years of age) (19). We identified the PCS cut-off value as 17 , as identified by Suren et al. (6) in their study where they performed the reliability and validity tests for PCS level in the Turkish community (PCS $\geq 17$ : high, PCS $<17$ : normal).

PCS has also been reported to be associated with the level of anxiety and depression. In this respect, it has been stated that it was more likely for perioperative pain to become chronic in cases of insufficient postoperative analgesia treatment in patients with high levels of anxiety and depression $(20,21)$. In our study, we assumed that the complications could be reduced by determining the sedation level through identifying the pain catastrophizing based on the anxiety level of the patient, which could be predicted by the PCS level.

\section{Study Limitations}

Despite its clear conclusions, our study also had certain limitations. These were the small number of cases and the fact that the levels and amounts of analgesia were not monitored during the identification of pain and catastrophizing scales of the patients due to the short period 
of procedure. In addition, a perioperative anxiety scale was not used apart from the scales we administered. Despite the fact that PCS involved three different types of questions, which were rumination, magnification and helplessness, the sub-dimensions of PCS were not analyzed in our study since the administration and compilation periods of our procedure was quite short.

\section{Conclusion}

In the present study, it was concluded that there was a correlation between the vascular access pain intensity and the consumption of sedation, and that the amount of sedation consumption increased based on the increase in the vascular access pain intensity. Certain perioperative complications can be prevented by administering sufficient sedation during the intervention and by determining the level of PCS during the preoperative period. Despite the limitations of the present study, it was concluded that the levels of DyNRS and PCS levels could affect the amount of sedation directly; however, we believe that more comprehensive studies would be beneficial.

\section{Ethics}

Ethics Committee Approval: This retrospective observational cross-sectional study was carried out in the University of Health Sciences Turkey, Trabzon Kanuni Training and Research Hospital Clinic of Endoscopy after obtaining the approval from the Clinical Research Ethics Committee (13/03/2020-KAEK-2020/15) of the same hospital.

Informed Consent: Were included in the study after obtaining written and verbal informed consent.

Peer-review: Externally peer-reviewed.

\section{Authorship Contributions}

Concept: A.A., A.Ş., P.D.A., Design: A.A., P.D.A., A.Ş., Data Collection or Processing: P.D.A, A.A., A.Ş., Literature Search: A.A., A.Ş., Analysis or Interpretation: A.Ş., Writing: P.D.A., A.Ş.

Conflict of Interest: No conflict of interest was declared by the authors.

Financial Disclosure: The authors declared that this study has received no financial support.

\section{References}

1. Salo M, Collin P, Kyrönpalo S, Rasmussen M, Huhtala H, Kaukinen K. Age, symptoms and upper gastrointestinal malignancy in primary care endoscopy. Scand J Gastroenterol 2008;43(1):122127.
2. Bilen A, Demirdağ H, Erdem E, Coşgun S, Demirtunç R. A prediction study between patients with the presence of alarm symptoms and organic pathology in upper gastrointestinal tract endoscopy. Endoscopy 2015;23(2):44-49.

3. Faigel DO, Eisen GM, Baron TH, Dominitz JA, Goldstein JL, Hirota WK, et al. Preparation of patients for GI endoscopy. Gastrointest Endosc 2003;57(4):446-450.

4. Sullivan MJL, Bishop SR, Pivik J. The Pain Catastrophizing Scale: Development and validation. Psychol Assess 1995;7(4):524-532.

5. Huskisson E, Jones J, Scott PJ. Application of visual-analogue scales to the measurement of functional capacity. Rheumatology 1976;15(3):185-187.

6. Suren M, Kaya Z, Gokbakan M, Okan I, Arici S, Karaman S, et al. The role of pain catastrophizing score in the prediction of venipuncture pain severity. Pain Pract 2014;14(3):245-251.

7. Grosen K, Vase L, Pilegaard HK, Pfeiffer-Jensen M, Drewes AM. Conditioned pain modulation and situational pain catastrophizing as preoperative predictors of pain following chest wall surgery: A prospective observational cohort study. PLoS One 2014;9(2):e90185.

8. Høvik LH, Winther SB, Foss OA, Gjeilo KH. Preoperative pain catastrophizing and postoperative pain after total knee arthroplasty: A prospective cohort study with one year follow-up. BMC Musculoskelet Disord 2016;17(1).

9. Penprase B, Brunetto E, Dahmani E, Forthoffer JJ, Kapoor S. The efficacy of preemptive analgesia for postoperative pain control: A systematic review of the literature. AORN J 2015;101(1):94-105.e8.

10. Ip HYV, Abrishami A, Peng PWH, Wong J, Chung F. Predictors of Postoperative Pain and Analgesic Consumption: A Qualitative Systematic Review. Anesthesiology 2009;111(3):657-677.

11. Özalp G, Sarioglu R, Tuncel G, Aslan K, Kadiogullari N. Preoperative emotional states in patients with breast cancer and postoperative pain. Acta Anaesthesiol Scand 2003;47(1):26-29.

12. Wright D, Hoang M, Sofine A, Silva JP, Schwarzkopf R. Pain catastrophizing as a predictor for postoperative pain and opiate consumption in total joint arthroplasty patients. Arch Orthop Trauma Surg 2017;137(12):1623-1629.

13. Granot M, Ferber SG. The roles of pain catastrophizing and anxiety in the prediction of postoperative pain intensity: a prospective study. Clin J Pain 2005;21(5):439-445.

14. Pyati S, Gan TJ. Perioperative pain management. CNS Drugs 2007;21(3):185-211.

15. Papaioannou M, Skapinakis P, Damigos D, Mavreas V, Broumas $\mathrm{G}$, Palgimesi A. The role of catastrophizing in the prediction of postoperative pain. Pain Med 2009;10(8):1452-1459.

16. Tharakan L, Faber P. Pain management in day-case surgery. BJA Educ 2015;15(4):180-183.

17. Pavlin JD, Sullivan MJL, Freud PR, Roesen K. Catastrophizing: A Risk Factor For Postsurgical Pain. Clin J Pain 2005;21(1):83-90.

18. Lautenbacher S, Huber C, Baum C, Rossaint R, Hochrein S, Heesen M. Attentional Avoidance of Negative Experiences as Predictor of Postoperative Pain Ratings and Consumption of Analgesics: Comparison with Other Psychological Predictors. Pain Med 2011;12(4):645-653.

19. Ruscheweyh R, Nees F, Marziniak M, Evers S, Flor H, Knecht S. Pain catastrophizing and pain-related emotions: influence of age and type of pain. Clin J Pain 2011;27(7):578-586. 
20. Rudin A, Wölner-Hanssen P, Hellbom M, Werner MU. Prediction of post-operative pain after a laparoscopic tubal ligation procedure. Acta Anaesthesiol Scand 2008;52(7):938-945.
21. Lundblad H, Kreicbergs A, Jansson KA. Prediction of persistent pain after total knee replacement for osteoarthritis. J Bone Joint Surg Br 2008;90(2):166-171. 